\title{
Assessment of spermatogenesis by fine needle aspiration of testes in patients with azoospermia
}

\author{
Ibrahim K. S. \\ From the Department of Pathology, College of Medicine, University of Mosul, Mosul, Iraq. \\ Correspondence: Ibrahim K. S. drkasim51@yahoo.com.
}

(Ann Coll Med Mosul 2013; 39 (2): 143-146).

Received: 10 ${ }^{\text {th }}$ Jan. 2013; Accepted: $18^{\text {th }}$ Jun. 2013.

\begin{abstract}
Background and objectives: Recent advances of Invitro Fertilization (IVF) and Intracytoplasmic Sperm Injection (ICSI) combined with the progress in sperm retrieval from testes have provided a hope for azoospermic patients to become fathers. The aim of this study is to describe the cytological features of the cells aspirated from testes of patients with azoospermia and to select those who have mature spermatozoa in their aspirate for assisted fertilization.

Design and setting: A descriptive study (case series) conducted in private clinic from Jan. 2007 to Sept. 2012.

Patients and methods: Under local anasthesia Fine Needle Aspiration Cytology (FNAC) was performed on 250 patients whose sperm count was zero in at least three consecutive semen samples.

The size of the testes was measured and recorded for each case. The cytological features of the aspirated cells were described and the patients who have mature spermatozoa were identified for assisted fertilization.

Results: Normal spermatogenesis was found in 54 patients (21.6\%), complete maturation arrest at primary spermatocytes in 95 patients (38\%), complete maturation arrest at secondary spermatocytes in 32 patients $(12.8 \%)$, germ cell aplasia in 62 patients $(24.8 \%)$, and atrophic testis in 7 patients $(2.8 \%)$. The mean age of the patients was 29.8 years. Regarding the greatest dimension of the testes, there was a significant difference in the greatest dimension of atrophic testes and in testes with germ cell aplasia, from the other groups. The procedure was well tolerated by the patients and no complications were encountered.

Conclusions: The technique can differentiate obstructive from intrinsic causes of azoospermia. It is simple, quick, cost effective and free from complications.
\end{abstract}

Keywords: FNAC, testis, infertility azoospermia.

تقييم تكوين النطف بواسطة الرشف بالإبرة الدقيقة في المرضى المصابين بإنعدام النطف

$$
\text { فرع الأمر اض، كلية الطب، جامعة المبرصيّ، الموصل، العراق }
$$

الخلقية والأهداف: التطور الحاصل في الإخصاب في المختبر وزرق النطف داخل السايتوبلام بالإضافة إلى التطور في الحصول

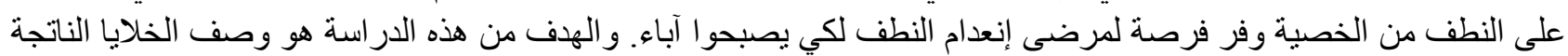

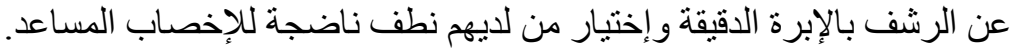

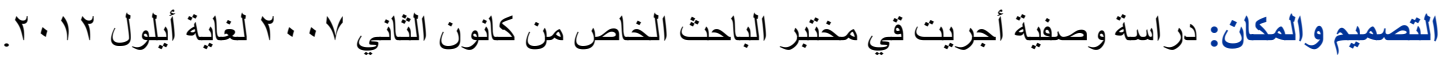

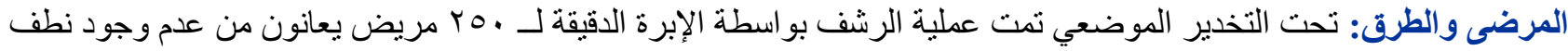

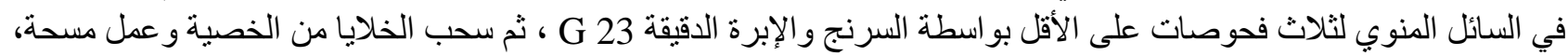

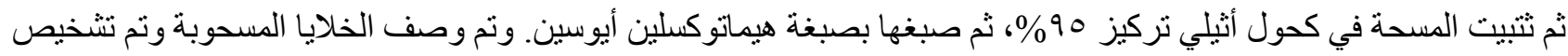

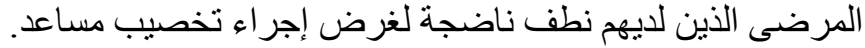

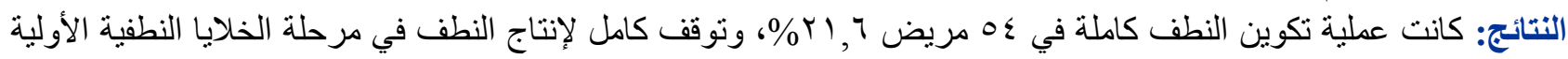

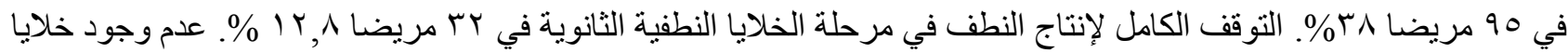




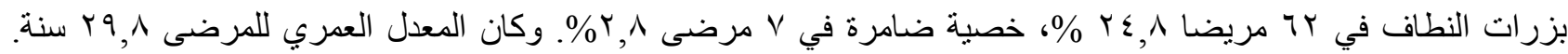

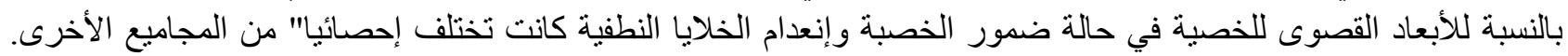

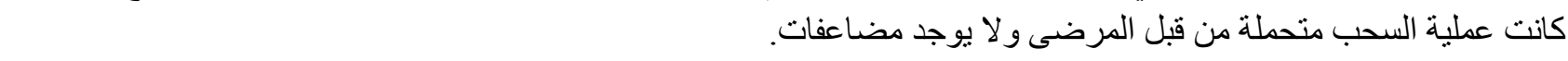
الاستنتاج: بواسطة هذه الطريقة يمكن معرفة أسباب إنعدام النطف (الإنسداد أو أسباب في الخصية). كانت الطريقة سهلة وسريعة ولم تكلف كثير ا". وكانت خالية من المضاعفات.

\section{INTRODUCTION}

nfertility is a common problem worldwide. ${ }^{1}$ Azoospermia is the most severe form of male factor infertility. It is present in $5 \%$ of infertile couple in Netherland, ${ }^{2}$ in $9 \%$ of infertile couple in France $^{3}$ and in $38.3 \%$ of infertile men in India. ${ }^{4}$

Azoospermia was a hopeless cause of infertility, but after the introduction of invitro fertilization (IVF), sperm retrieval from the testis and surgical management of obstruction, gave a hope for fatherhood in those couples. ${ }^{5,6}$

Fine needle aspiration of the testis as an alternative to open biopsy has been used to characterize the state of infertility for the last 40 years ${ }^{7}$ It is well recognized as a reliable and informative technique in assessment of spermatogenesis, ${ }^{5,6,8,9}$ yet nobody has tried this technique in our locality.

The aim of this study is to use FNAC of testis:

1. To assess spermatogenesis.

2. To categorize underlying pathologies.

\section{PATIENTS AND METHODS}

From Jul. 2007 to Jul. 2012, two hundred and fifty patients with azoospermia, (sperm count is zero in at least three semen analysis) were received in the private clinic, referred from gynecologist and andrologist colleaques from various units.

The procedure was explained for the patient and consent of the patient was obtained.

The age of the patients and the greatest dimension of the testis were recorded.

FNAC from one testis is performed under local anesthesia using disposable syringe and fine needle (gauge $23 \mathrm{G}$ ). A smear of the aspirated material is prepared, fixed in $95 \%$ ethanol and stained by $\mathrm{H} \& \mathrm{E}$ stain.

Statistical analysis was performed using one way ANOVA test. $F=306.46$ to see if there is any significant correlation between size of testes and state of spermatogenesis.

\section{RESULTS}

The technique is simple, quick and well tolerated by most of the patients. No complications were encountered.

The age of the patients ranged from 20 to 45 years with a mean of 29.8 years (Table 1 ).

The greatest dimension of the testis varied according to the underlying lesion from 1 to $5 \mathrm{~cm}$ (Table 2). The testes were significantly smaller in atrophic testis and those with germ cell aplasia than the other groups of lesions (Table 2).

Table 1. Mean age of the study population.

\begin{tabular}{|c|c|c|c|c|}
\hline \multirow{2}{*}{$\begin{array}{c}\text { Normal and } \\
\text { Testicular } \\
\text { lesions }\end{array}$} & \multirow{2}{*}{ No. } & \multicolumn{3}{|c|}{ Age (years) } \\
\hline & & Mean \pm SD & Minimum & Maximum \\
\hline $\begin{array}{l}\text { Normal } \\
\text { spermatogenesis }\end{array}$ & 54 & $30.6 \pm 3.53$ & 24 & 40 \\
\hline $\begin{array}{l}\text { Complete } \\
\text { maturation arrest } \\
\text { at primary } \\
\text { spermatocyte }\end{array}$ & 95 & $29.5 \pm 5.20$ & 20 & 45 \\
\hline $\begin{array}{l}\text { Complete } \\
\text { maturation arrest } \\
\text { at secondary } \\
\text { spermatocyte }\end{array}$ & 32 & $27.9 \pm 3.40$ & 22 & 36 \\
\hline $\begin{array}{l}\text { Germ cell aplasia } \\
\text { (Sertoli cell only } \\
\text { syndrome) }\end{array}$ & 62 & $32.4 \pm 4.2$ & 22 & 38 \\
\hline Atrophic testis & 7 & $32.0 \pm 6.56$ & 25 & 42 \\
\hline Total & 250 & $29.8 \pm 4.53$ & 20 & 45 \\
\hline
\end{tabular}

Table 2. Mean of greatest dimension of the testis in normal and different types of testicular lesions.

\begin{tabular}{|c|c|c|c|}
\hline $\begin{array}{c}\text { Normal and Testicular } \\
\text { lesions }\end{array}$ & No. & $\begin{array}{l}\text { Size of testis } \\
\text { (centimeter) } \\
\text { Mean } \pm S D\end{array}$ & $\begin{array}{c}\text { P- } \\
\text { value }\end{array}$ \\
\hline $\begin{array}{l}\text { Normal } \\
\text { spermatogenesis }\end{array}$ & 54 & $4.5 \pm 0.50$ & \multirow{5}{*}{0.0001} \\
\hline $\begin{array}{l}\text { Complete maturation } \\
\text { arrest at primary } \\
\text { spermatocyte }\end{array}$ & 95 & $4.09 \pm 0.69$ & \\
\hline $\begin{array}{l}\text { Complete maturation } \\
\text { arrest at secondary } \\
\text { spermatocyte }\end{array}$ & 32 & $3.9 \pm 0.69$ & \\
\hline $\begin{array}{l}\text { Germ cell aplasia } \\
\text { (Sertoli cell only } \\
\text { syndrome) }\end{array}$ & 62 & $1.9 \pm 0.42$ & \\
\hline Atrophic testis & 7 & $1.0 \pm 0.00$ & \\
\hline
\end{tabular}


Obstructive azoospermia was diagnosed by presence of mature spermatozoa. A finding which indicates complete maturation. It was found in 54 cases $(21.6 \%)$ (Table 1). Complete maturation arrest at primary spermatocyte, was characterized by absence of mature spermatozoa and lack of maturation beyond primary spermatocytes. Primary spermatocytes are large rounded cells with relatively large nuclei present singly and in small groups. Ninety five patients (38\%) were diagnosed as such (Table 1).

Complete maturation arrest at secondary spermatocytes revealed secondary spermatocytes, with absence of mature spermatozoa. Secondary spermatocytes are rounded cells smaller than primary spermatocytes with dense nuclei. Thirty two patients were encountered in this group (12.8\%). (Table1).

Germ cell aplasia (Sertoli cell only syndrome) showed absence of germ cells. The smear contained Sertoli cells and interstitial cells of Leydig only. It was found in 62 patients $(24.8 \%)$ (Table1). Sertoli cells are elongated cells (columnar cells) with basal nuclei. Interstitial cells are large polyhedral cells with rounded nuclei and esinophilic cytoplasm.

Atrophic testis revealed absence of germ cells, Sertoli cells and interstitial cells of Leydig. It was found in 7 patients $(2.8 \%$ ) (Table 1 ).

\section{DISCUSSION}

Although the technique was reported by many others, ${ }^{6,8-11}$ however it is the first study of this kind in our locality. It is an outpatient procedure and tolerable by most of the patients. Assessment of the accuracy of the procedure was not the aim of this study as it has been assessed repeatedly in other studies with accuracy rate ranging from $87 \%$ to $100 \%,{ }^{5,6,8,9}$

By FNAC it was possible to differentiate post testicular (obstructive) cases from intrinsic testicular cases in 54 patients $(21.6 \%$ of the cases) A figure which is lower than that reported by Dajani YE and Kilani $Z,{ }^{12}$ this difference can be attributed to the type of sample i.e number of aspirates, and the regional variation of underlying cause of azoospermia. ${ }^{1,4,13}$

The finding of mature spermatozoa in the aspirate is an important step in the management of infertility as it provides a hope for biologic fatherhood either by invitro fertilization (IVF), ${ }^{6}$ or by surgical correction of vaso-epididymal junction, ${ }^{5}$ eliminating unnecessary and useless medical treatment in such cases.

The age of infertile men seeking advice for infertility in this study is comparable to those reported by Kurien et al. ${ }^{8}$ (Table1).

Regarding the greatest dimension of the testes, in germ cell aplasia, atrophic testis and Sertoli cell only syndrome, the testes were significantly smaller than the testes in the other groups ( $p$ value is 0.0001) (Table 2). A finding which is helpful in predicting the underlying pathology.

Bleeding and epididymitis were reported by Piato et $\mathrm{al}^{14}$ after the use of spring-loaded biopsy. Such complications were neither encountered in this study nor reported by the use of Fine needle Aspiration. ${ }^{10,14}$

Acknowledgments: The author is grateful to Ahmad Jassim Al-Husainy, a gynecologist at Mosul College of Medicine, Zayd Saad Al-din, an urologist at Mosul College of medicine and Idrees Danoon, a gynecologist at Mosul Health Office for their help and cooperation in this study.

\section{REFERENCES}

1. Boivin J, Bunting L, Collins JA, Nygren KC. International estimate of infertility prevalence and treatment-seeking: potential need and demand for infertility medical care. Hum. Reprod. 2007;22(6) :15061512.

2. Van Peperstraten A, Proctor ML, Johnson NP, Philipson G. Technique for surgical retrieval of sperm prior to intracytoplasmic sperm injection (ICSI) for azoospermia. Cochrane Database syst Rev.2008;16 (2):CD002807 .

3. Thonneau $P$, Marchand $S$, Tallec $A$, et al. Incidence and main causes of infertility in a resident population (1850000) of three French regions (1988-1989). Hum Reprod.1991;6 (6):811-816.

4. Mehta RH, Makwana S, Ranga GM, Srinivasan RJ, Virk SS. Prevalences of oligospermia and azoospermia in male partners of infertile couples from different parts of India. Asian Journal of Andrology 2006;8:89-93.

5. Kumar R, Gautam G, Gupta NP, Aron M, Dada R, Kucheria $\mathrm{K}$, et al. Role of testicular fine needle aspiration in infertile men with clinically obstructive azoospermia. Natl Med J India 2006 Jan-Feb;19(1):18-19.

6. Wikipedia. FNA mapping. [cited 2012]. Available from: URL:http://en.wikipedia.org/wiki/FNA-Mapping.

7. Hendricks FB, Lambird PA, Murph GP. Percutaneous needle biopsy of the testis. Fertil Steril 1969;20:478-81.

8. Kurien A, Mammen K, Jacob S. Role of fine needle aspiration cytology (FNAC) of testes in male infertility.Indian J Urol. 2003;19:140-144.

9. Stelleta C, Juyena NS, Pance Salazar DP, Ruiz J, Gutierrez G. Testicular cytology of alpaca: Comparison between impressed and smeared slides. Animal Reproduction Science 2011 May;125 (1-4):133-137. 
10. Yadav SP, Gopal M, Chadha I, Gulati P, Sharma R, Marya SK, et al. Comparative evaluation of fine needle aspiration cytology and biopsy of testis in diagnosis of male infertility. J India Med Assoc. 1997 May;95 (5):12934.

11. Verma AK, Basu D, Jayaram G. Testicular cytology in azoospermia. Diagnostic cytopathology 1993;9(1):3742.

12. Dajani YE, Kilani Z. Role of testicular fine needle aspiration in the diagnosis of azoospermia. Int $J$ Androl1988; 21(5):295-300.
13. Cates W, Farley TMM, Rowe PJ. Worldwide patterns of infertility: Is Africa different?. Lancet 1985; 326 (8455):596-598.

14. Piaton E, Fendler JP, Berger N, Perrin P, Devonec M. Clinical value of fine needle aspiration cytology and biopsy in the evaluation of male infertility. A comparative study of 48 infertile patients. Arch Pathol Lab Med 1995; 119 (8):722-726. 